\title{
肺炎死亡數と寒冷前線 との關係
}

(東京帝國大學醫學部鲸生學教室, 主任 田宮猛雄教授)

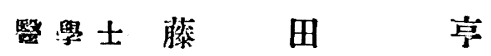

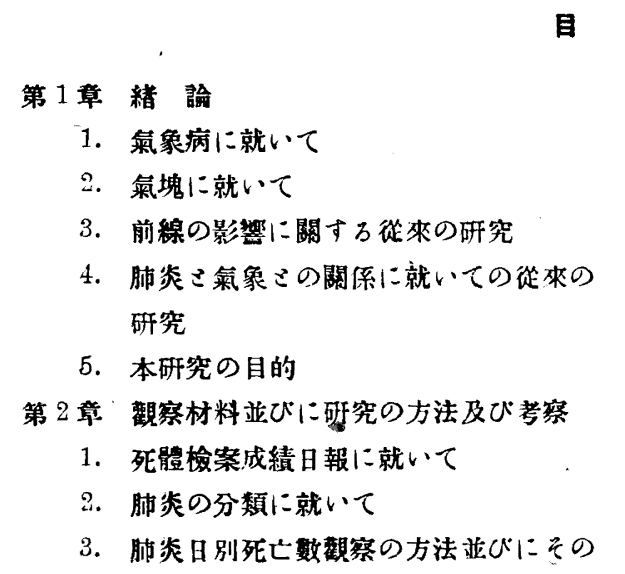

次

\section{第 1 章，緒論}

\section{1. 氣象病に就いて}

氣象殊に氣象激變の生理的影響は古來周く知られ，醫學としては，古くはヒポクラテスが， 『空氣, 水及び土地に就いて』に於いて, 氣橡が疾病の成立に及性す影響に就いて述べて居る。

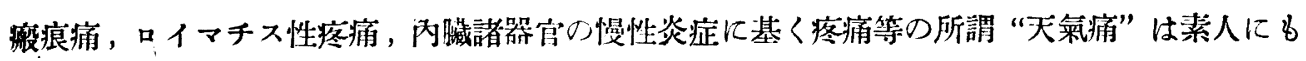
熟知されて居る。かくの如く氣缘變化に依つて誘發され惡化する疾患を氣像病上名づけられ， 多數の疾患が舉げられて居る。而してかくの如き氣缘病を觀察するに當つて，倜くの策象要素 即ち, 氣娾, 氣溫, 濕底, 風速, 風向, 降水量, 雲量, 日照時間等と健康狀態とを關係づけん とする試みは屚々なされた。郎ち，古くは Harald Ackermann (1854)，Loeschner (1856)， Altschul (1891), 近世に至り, Ruhemann (1906), Brezina (1914), Schade (1919), Hellpach (1923), Smiley (1926), Ledrer (1928), de Rudder (1928, 29), Heuss (1929), Rechter (1931), Walter (1932), Höring (1933)，杉原 (1933), Lampert (1934)，山野，塚越 (1935)， 柏井（1940）等其の數は著しく多いが何れも滿足すべき結果に至らなかつた。疾病の最惡の場 合である死亡と氣象との關係に就々ては, Helly (1920), E. Jenny (1931), V. Struppler (19 32)，G. Ortmann (1933)，田爪，山口，川人，柏井等の研究がある。田爪，山口は死亡苴數 と氣溫, 氣埾の日變化との關係を見, 川人, 柏井は死亡率之氣溫, 氣盟, 濕度等との部分相關 
を見たのであるが何れも同㥞に滿足すべき絬果に到達して居ない。

\section{2. 氣塊に就いて}

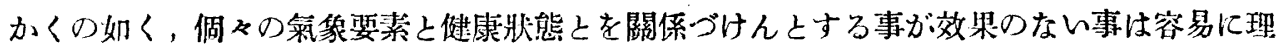
解出來る。何とならげ，生體は綜合した氣象の影響の下にあるからである。ての見地より，19 29 年 F. Linke が綜合した氣集を定義する氣塊（Luftkörper）と健康非態との關係を提唱して

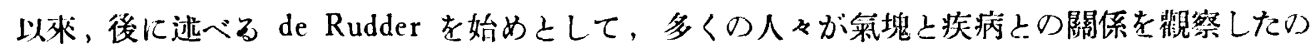
である。

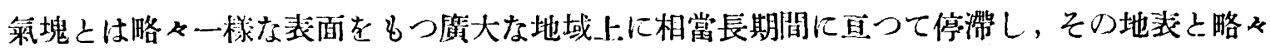
平衡狀態に遠した均一なる大氣の團塊を云ひ，水平方向の擴がりは數百籸以上あるが，高さは 數䉼乃至 10 䉼內外である。

かくの如き筷塊を育む地方を生地と名づけると生地たるべき條件は

1）略々一梯な表面をもつ廣大な地域である事。

2）大篓が相當長期に亘つて該地點に停滞し得る事。

である・特に第 2 の條件に依り，生地は地域的な制約考受ける。即ち，大氣の大循環に依り，

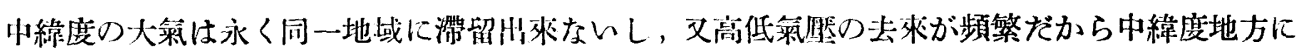
生地はない。極や赤道近くでは，大循環の强さもずつと尠くなるから，生地は極や赤道近くに

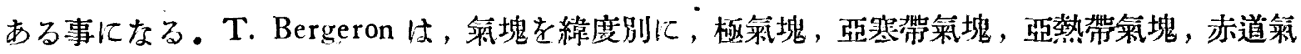

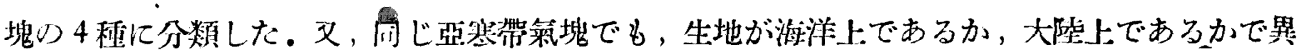
るから, 更に夫ょを2 分して, 海洋氣塊, 大陸氣塊とした。

次に重要なる事は氣塊の經路である。即た，氣塊は生地を去ると共に特性が次第に變化する が，その變質は生地を州苝してからの經路に依るのである。

或る一定の季第に特定の生地老州弡して，特定の經路を經た篓塊が，荣地點に到達したとす ると，生地で特定り性質をも七，夫火の經路により或る特定の變質を受けた氣塊が柬る事にな るから，夫及特有の天氣を現はす事になる。

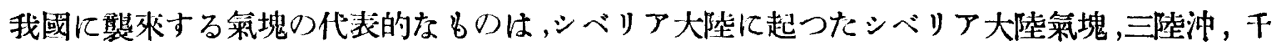
島方面に發したオホーツク潅氣塊，南方海上ょり吹走して來る小笠原氣塊であると云はれて居

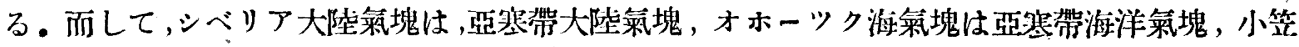
原氣塊は，亞熱帶海洋氣塊である。荒川秀俊氏に從ひ，各氣塊の屬性を示すと次の通りである。

\begin{tabular}{|c|c|c|c|c|c|c|}
\hline 地 & 稱 & 出 現 時 期 & 圭 & な & 嫐 & 質 \\
\hline シへリア大陸 & $\begin{array}{l}\text { シへリア大陸 } \\
\text { 氣塊 }\end{array}$ & 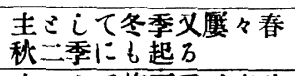 & $\begin{array}{l}\text { 1) 黄海, } \\
\text { g) 先つ支 }\end{array}$ & 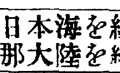 & 無て來万 & 沉東進し來る \\
\hline $\begin{array}{l}\text { 才ホーツク海 } \\
\text { 千島沖 }\end{array}$ & 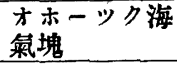 & 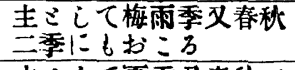 & & 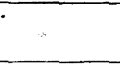 & & \\
\hline 本邦南方海上 & 小笠原氣塊 & $\begin{array}{l}\text { 表きして夏季又春秋二 } \\
\text { 季にもお }\end{array}$ & & & & \\
\hline
\end{tabular}




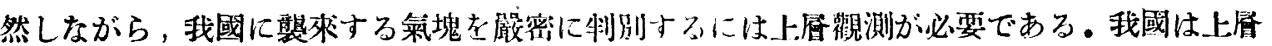

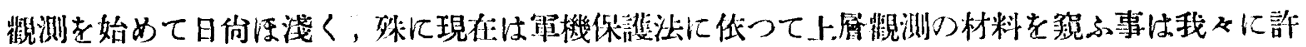

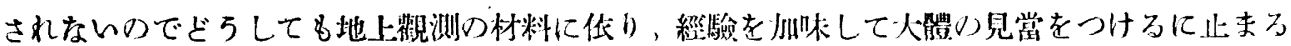
৩である。

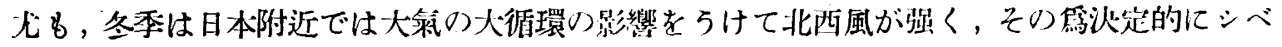
リヤ大陸氣塊の影響を受け，オホーツク海菜地又は小笠原策地の影響は㱠んど浆はれない。從 つて冬季に於けるシベリヤ大陸氣塊の判別は符易である。

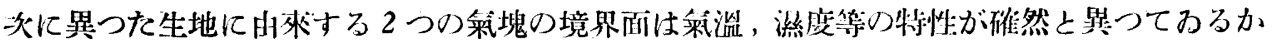

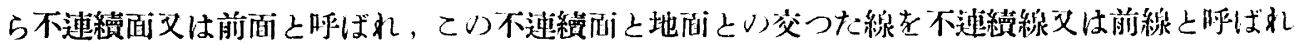
てみる。

向ほ，暖い氣塊が椧い莱塊り上をはひ上る場合には之を泪暖前線上云ひ，冷い氣塊が下側に 笖入して暖い掬塊を推し上げる場合は寒冷前線と稚してるる。

一般に寒冷前線は頗る銳い事が多く，その幅は 10 䉼程度であるが，㴘暖前線は稍々ぼけて みてその幅は 100 䉼內外である。

一地方が前線に化つて通過せられると天候の激變が起るから，前線の通過が生體に影響を及 将すと云ふ事は容易に理解出來るりである。

\section{3. 前線の影響に關する從來の研究}

前線の通過が生體に影響を及ぼすと云ふ事を始めて組織的に研究したのは de Rudder であ る.彼は 1929 年氣像病理學 (Meteoropathologie) なる一分科考興し, 疾患の向氣象性 (Meteorotropismus）を研究した。彼化低れば，或る疾患並びに症狀は常に㕍々或る一定の日におて

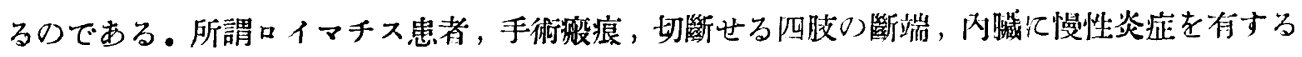
人等の，天氣痛”は素人にも周知の事實である。か〉る病的現象が超偶然的に (überzufällig), 頻繁に，同時的に，協同的に起る事は臨牀的にも直接唯祭される。若し䈝はしい場合は超偶然 性（Überzufälligkeit）の證明が統計學的方法に侁つて行はるべきであると述べてるる，而し

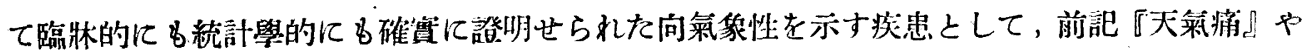

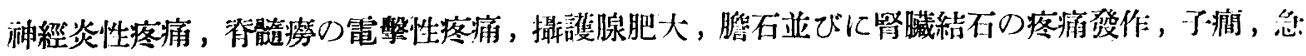
性喉頭クルツプ郎ち，瓜疹，ヂフテリア，並びにグリッペのクルツプ，喀血，湖炎（クルツプ

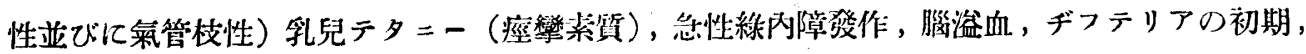
一般の死亡の發生等を㼂げ，それに亞ぐものとして，フリクテンの再發，手術後合侀症，狹心

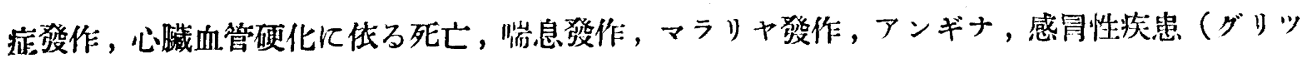
ペ,インフルェンザ) 等を舉け゚てみる。

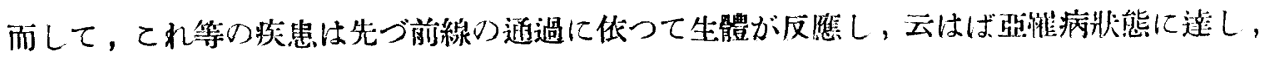


沃包の前線通過に低つて異常の所見を呈し，遂に發疙に至るものであると述べてるる。郎ち，

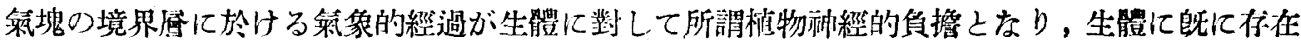
してるた支配能力並びに適應能力に打勝つて發病するに至ると迠へてるる。

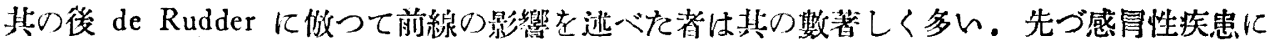
關しては W. Rimpau (1937), Ernst Edens (1938), A. Weber (1938), E. Flach (1938), W. Pfanner (1939), Jakob Bauer (1938), Tichy (1938), Peterson (1938), 等の報告があ

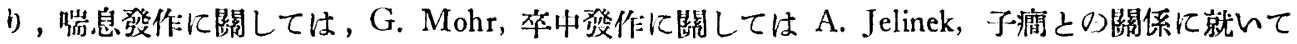
は Jacob (1935), Latzka (1935), Eufinger u. Weickerscheimer (1933), Louros u. Panajaton (1938)，等の報告があり，何れも前線逊過之疾病との密接な關係を認めてみる。

其心他 E. Rappert（1935）忙，手術後呼吸器合倣症 策管枝炎，肺炎，肋膜炎，急性炎症

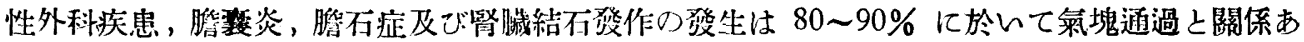
りと云ひ，F. Peterson 及び F. Benell（1935）は，脊體前觔は紐育州に於ける觀察に低れ ば，同州老極氣塊，時に熱帶氣塊が浸襲する時多數梫生すると逃べてるる。

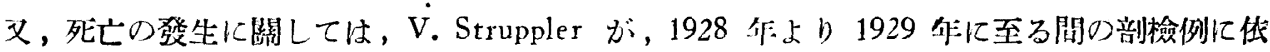
つて前線の影響を碓認したと云ひ，Ortmannは，似林に於ける剖檢例 16.382 例に低れば,前 線逊過の日の死亡數の平均は，その前日の死亡數の平均より $16.2 \%$ 高率であると述べてるる。

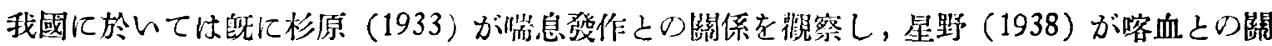
係を嘏告してるるが，何れも一企間の覞察に止まり，症例が少く，且つ統計學的に處理されて 居らず, de Rudderの所謂超偶然性が示されてなない。又，我國に繁來する氣塊の制別は既に

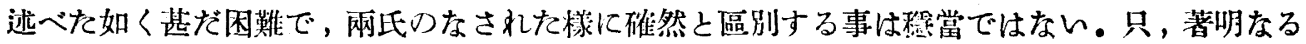
寒椧前線のみを探り上ぐる事が許されると考へられる。てれ，余が本研究に於いて，肺炎死亡 發生之前線との關係を觀察するに當り，著明なる寒冷前線のみを探り上げた所以である。

\section{4. 肺炎と氣象との關係に就いての從來の研究}

肺炎が集團發生をする事に就いては前世紀上り報告がある。Port（1833）は，肺炎を著明な る氣商病なりと諭じ，Bein 並びに Knöven は，肺炎發生と天候の動播との著朋な關係を立猃

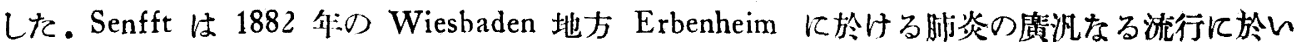
ては，日々の發生數が動播を示し，それが氣朕計の動播上一致せる事を述べてるる．Seibert は前世紀の 80 年間に亘り觀祭して，肺炎發生の增加に充分なる因子として，低溫，高缹，强 風を舉げ得ると信じ，乙れ等の因子が互に協力すればする程その影響为增加し，呼吸粘膜炎症 の發生には，何れも同核な氣邹的影響が見出されると述べた。Joppich は氣象不安定をクルツ プ性肺炎墢生の標淮的因子として引用してるる。H. Meseth (1936) は, 5 年間に 262 例の プ性肺炎，1035 例のカタル性肺炎老觀察し，肺炎の發生は氣溫の絕對值とは無關係で，冬季 
に限らす他の時期㲸も見られるから基冷作用に依るものとは思はれぬ。之に反して，寒溫兩前

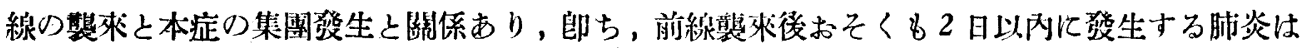
全數の $98.5 \%$ を占めてねると述べてるる。

然るに我國に於ては，肺炎死亡發生と前線との關係を觀察した者は余察閆にして之を知らな n.

\section{5. 本研究の目的}

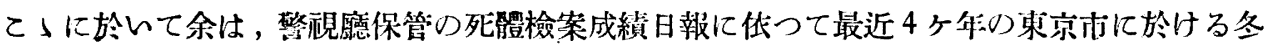
季昁炎死亡數を逐日的に求め，同時に，中央氣任臺發行の天氣圖に低つて同期間に，東京方を 著明なる寒冷前線が通過した日とその大體の時刻を知り；兩者に低り，

1）肺炎死亡は集圄發生をなすや

2）肺谈死亡發生の餘效如何

3）肺炎死亡㡎生之寒冷前線道過との關係如们 の三點に就き檢討すべく企圖したつである

\section{第 2 章 觀察材料並びに研究の方法及び考察}

\section{1. 死體檢案成樍日報に就いて}

余が東京市に於ける日別肺炎死亡數を求めた警視廳保管の死體檢案成績日報とは，警視廳管 下の次の警察署郎ち，㱀町，丸八內，錦町，西神田，萬世橋，久松，堀留，新場橋，築地，京

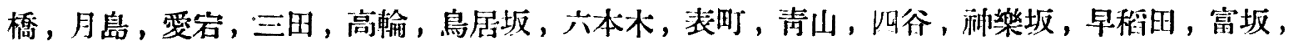

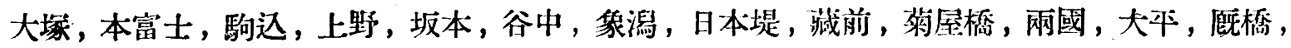

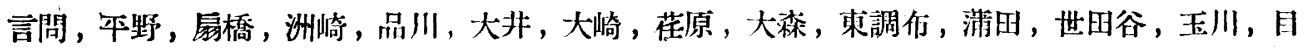

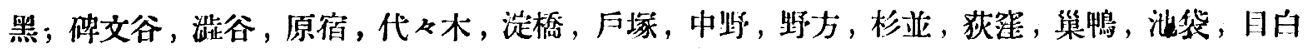

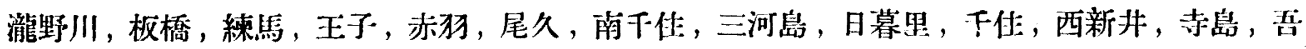
㸌, 葛飾, 鼠戶，砂町，小松川，八王子，水上の各警察署がその管內に死亡者ありし時は，そ の姓名, 職翡, 生年月日, 發病年月日, 死亡月日時间, 死亡の場所, 主治醫の姓名, 並びに病

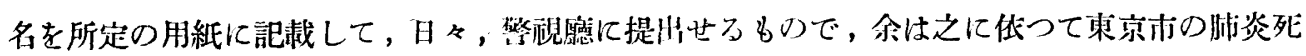
亡數を逐日的に知万事存得た。

\section{2. 肺咨の分類に就いて}

肺炎は臨牀家，病理學者，流行病學者，細菌學者等に訨つて種々の方面から分類が行はれて

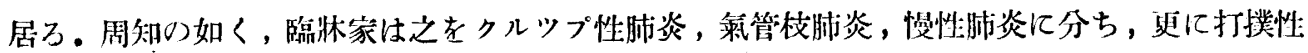




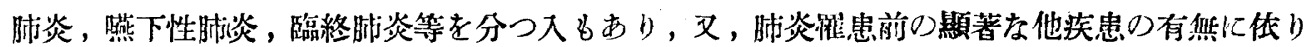
一次性肺炎，二次性肺炎之分け，又はアレルギーの立場から，一中心性肺淡，多中心性肺炎に 分類せんとする人もある。又，近時，肺㷋猗原菌の研究が進んで，原因菌に依つて分類せんと する企が探为せられ，Reimann は先づ火きく

1）特殊型肺炎

2）系統的疾患の一部として發生した肺炎

3）急性並びに慢性疾患，機慽的原因，ショツク，老䄇等によつて二次的に起る肺炎混合 感染

4) 非傳染性肺炎

に分けてるる。

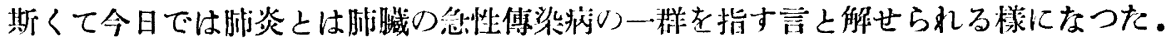

\section{3. 肺炎日別死亡数觀察の方法並びにその結果及び考察}

余は前記の死體檢案成䋶日㪕中より肺炎死亡數老集計するに當り，Reimann の分類の2）3）

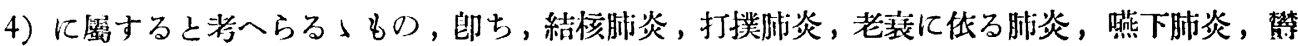
血肺炎，手術後肺炎等は之を除外し，椸疹肺炎，百日陔肺炎，’インフルェンザ肺炎等の Reimann の分類の 1) に虽するものを急性肺炎（クルツプ性肺炎），氣管枝肺炎（カタル性肺炎） 之同時に集錄し，向ほ感冒，インフルェンザが肺淡の誘因となる事は明かであるから，急性氣 管枝郧答兒，感冒，グリツペ，インフルェンザ等にて死亡せるもいも肺炎として探用した。

かくして得た，昭和 14 年 11 月 1 日より翌年 10 月 31 日まで一ケ年の日别肺炎死亡數は 第一翌の通りである。

第1表 昭和 14 年 11 月 1 日上り柆年 10 月 31 日 に至る一ら企澗日别肺炎死亡數 (東京市)

\begin{tabular}{|c|c|c|c|c|c|c|c|c|c|c|c|c|}
\hline $\mathrm{G}^{\text {月 }}$ & $\begin{array}{c}\text { 14竹 } \\
11\end{array}$ & 12 & $\begin{array}{c}\text { 15年 } \\
1\end{array}$ & 2 & 3 & 4 & 5 & 6 & 7 & 8 & 9 & 10 \\
\hline 1 & 11 & 36 & 55 & 50 & 44 & 48 & 34 & 18 & 14 & 9 & 12 & 7 \\
\hline 2 & 10 & 24 & 58 & 72 & 52 & 45 & 82 & 82 & 7 & 10 & 6 & 7 \\
\hline 3 & 17 & 32 & 57 & .52 & 56 & 69 & 23 & 17 & 13 & 16 & $\tilde{o}^{1}$ & 9 \\
\hline 4 & 12 & 40 & 69 & 69 & 60 & 49 & 28 & 20 & 15 & 5 & 12 & 14 \\
\hline 5 & 24 & 43 & 65 & 60 & 64 & 45 & 22 & 23 & 10 & 6 & 12 & 11 \\
\hline 6 & 13 & 27 & 48 & 43 & 64 & 51 & 20 & 15 & 13 & $7)$ & 9 & 9 \\
\hline 7 & 17 & 35 & 59 & 60 & 47 & 57 & 36 & 20 & 21 & 5 & 2 & 14 \\
\hline 8 & 26 & 35 & 68 & 50 & 43 & 58 & 25 & 19 & 9 & 12 & 4 & 16 \\
\hline 9 & 12 & 41 & 45 & 57 & 51 & 51 & 26 & 25 & 6 & 11 & 6 & $\delta$ \\
\hline 10 & 14 & $-\quad 47$ & 56 & 66 & 37 & 41 & 15 & 17 & 5 & 6 & 3 & 3 \\
\hline 11 & 11 & 44 & 63 & 55 & 68 & 40 & 24 & 16 & 6 & 13 & 13 & 10 \\
\hline
\end{tabular}




\begin{tabular}{|c|c|c|c|c|c|c|c|c|c|c|c|c|}
\hline 1: & 19 & 47 & 73 & j0 & 40 & 48 & 30 & 10 & 4 & 11 & 13 & 9 \\
\hline 13 & 26 & 50 & 48 & 48 & 50 & 41 & 34 & 16 & 10 & 9 & 5 & 9 \\
\hline 14 & 10 & 48 & 66 & 45 & 53 & 50 & 21 & $8:$ & 8 & 6 & 8 & 9 \\
\hline $15^{\circ}$ & 27 & 56 & 60 & 73 & 64 & 33 & 15 & 17 & 10 & S & 10 & $1: 2$ \\
\hline 16 & 25 & 70 & 44 & 59 & 50 & 34. & 19 & 18 & 11 & 17 & 8 & 9 \\
\hline 17 & 12 & 70 & 55 & 57 & 47 & 33 & 85 & 15 & 13 & 7 & 10 & $1=$ \\
\hline 18 & 19 & 55 & 45 & 60 & 66 & 41 & 24 & 19 & 10 & 16 & 12 & 9 \\
\hline 19 & $1 \bar{\partial}$ & 447 & $45^{-1}$ & 48 & 63 & 31 & 19 & 16 & 14 & 11 & 4 & $1:$ \\
\hline 20 & 15 & 51 & 52 & 43 & 61 & 40 & 42 & 18 & 12 & $10^{\prime}$ & 6 & 18 \\
\hline 81 & $\Omega 0$ & 62 & 59 & $5:$ & 46 & דו & $\because 3$ & $8:$ & 13 & 4 & 14 & 11 \\
\hline$\therefore$ & 21 & 66 & 56 & 41 & 40 & 33 & $\therefore$ & 14 & 12 & $\delta$ & 11 & 9 \\
\hline בֶ & $\therefore 0$ & 66 & $62^{\prime}$ & 55 & 41 & 16. & 17 & 13 & 10 & 7 & 8 & 11 \\
\hline 84 & 13 & 62 & 64 & 54 & 42 & 202 & 23 & 13 & 11 & 11 & 9 & 11. \\
\hline מٓت & 18 & 56 & 54 & 5̃ & 51 & 17 & 20 & 8 & 14 & 10 & 1.1. & 14 \\
\hline 26 & 18 & $5 \tilde{5}$ & 55 & 34 & 48 & $\therefore 0$ & 19 & 13 & 11 & 6 & (9) & + \\
\hline 97 & 19 & 63 & 50 & 63 & 66 & 9 & 19 & 10 & 10 & 7 & 8 & 13 \\
\hline SS & $\therefore 4$ & 54 & 5.4 & 67 & 58 & ד & 15 & 17 & 7 & 8 & 9 & $1:$ \\
\hline$\because 9$ & $3 S$ & 55 & 48 & 41 & 49 & 34 & 15 & $1+$ & $=$ & 11 & 6 & 11 \\
\hline $30^{\circ}$ & 25 & 59 & 5 & & 53 & 32 & 16 & 9 & 4 & 11 & 10 & 13 \\
\hline 31 & - & 39 & 49 & & 44 & - & 89 & - & $i$ & 19 & & 13 \\
\hline 計 & 551 & 1.535 & 1.710 & 1.589 & 1.625 & 1.156 & 724 & $503^{\prime}$ & 314 & 299 & 257 & 326 \\
\hline
\end{tabular}

總計 366 日, 10,580

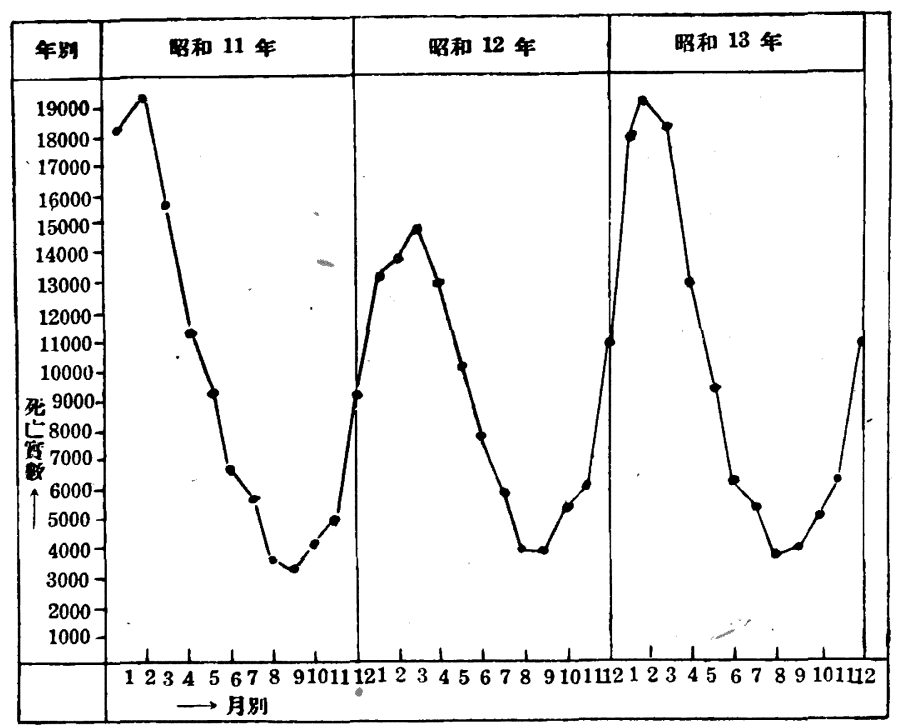

第 1 楒 最近三年間我國に於ける肺炎の月别死亡實數 (帝國統計年鑑) 


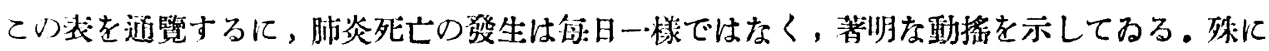
冬季に於いて荠しい，肺炎死亡が集橉發生をする事は明かで，本研究の目的の第一點は之にて 涬せられる。

炊に之を月別に集計すると，季節的變化のある事が見られる。節ち，第 2 表の如く，一年間

第 2 裴 昭和 14 年 11 月より昭和 15 年 10 月に 至る一ケ年間の月别敊炎死亡數 (東京市)

\begin{tabular}{r|c||c|c||c|c|c|c}
\hline 月 & 肺炎死亡數 & 月 & 肺炎死亡數 & 月 & 肺类死亡數 & 月 & 肺炎死亡數 \\
\hline 11 & 551 & 2 & 1,582 & 5 & 724 & 8 & 299 \\
12 & 1,535 & 3 & 1,625 & 6 & 503 & 9 & 257 \\
1 & 1,710 & 4 & 1,156 & 7 & 314 & 10 & 326 \\
\hline 計 & & & & & & 10,582 \\
\hline
\end{tabular}

に於いて，12月，1月，2月，3月の纤ら春にかけて最も多く，8月，9月の夏から秋に かけて最も少ん。

此の事は第一圖の最近 3 年閣我國に於ける肺炎の月别死亡實數に低る 女同㥞，1月，2月， 3 月最も多く, 8 月, 9 月最も少々.

郎ち，我國の肺炎死亡は冬季に最も多く發生する。

\section{4. 餘效に就いて}

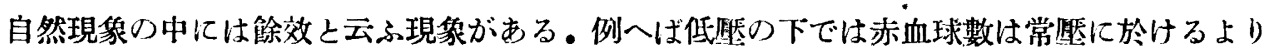

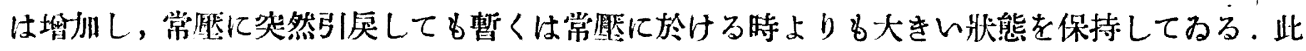
り㥞に外因を適當な强度で作用させた場合，又は外因が適當な强度で作用する場合，それ相賞 り結果が直ちに現れない場合にはての現象はての原因に對して餘效をもつと稱する。

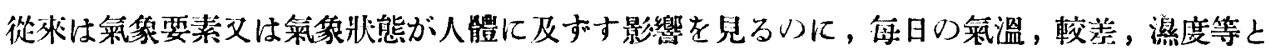
伯日の死亡數との相關係數を求むるに止まり，外界の影響が時間的に少しおくれて現れる場合

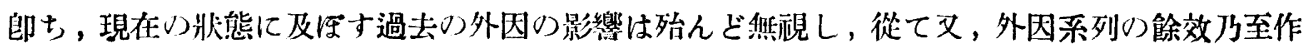
用は全く考虙されてなかつた。

ての)缺點圭除く方法に，高橋，伏見の發見した自巨相關法（又は相關係數法）がある。

自已相關法の要點は，若し次々と順序づけられた测定值の系列 $\left\{n_{i}\right\} か ゙ ， J$ 單位の週期を有す るならば $i$ 番目の要素の值 $n_{i}$ と $i+j$ 番目の要素の值 $n_{i+j}$ とは夫«その近傍に對して大小關

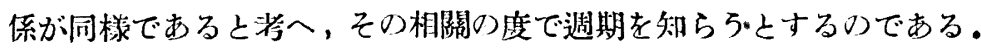

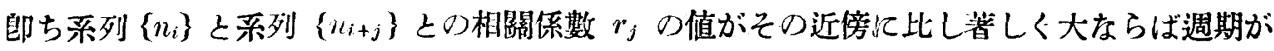

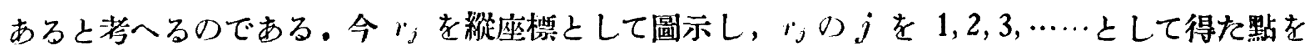
蓮ねる折線が $P$ 單位の週期をもつ正弦曲線を描くならば, 系列 $\left\{n_{i}\right\}$ は $p$ 單位の週期をもつと 
考へられる．而して， $r_{j}$ を計算する公式は次の逝りである。

今, 系列 $\left\{n_{i}\right\}$ の要素 $n_{i}$ の總數 $N$ が適虽に大きいとすると

$$
r_{j}=\frac{\sum_{i=1}^{N} n_{i} n_{i+j}-N\left(\frac{\sum_{i=1}^{N} n_{i}}{N}\right)^{2}}{\sum_{i=1}^{N}\left(n_{i}\right)^{2}-N\left(\frac{\sum_{i=1}^{N} n_{i}}{N}\right)^{2}} \text {. }
$$

但し變動に基く本均誤苃は $E\left(r_{j}\right)=\frac{1}{\sqrt{N}}$ である。

\section{5. 肺炎死亡数の餘效並びにその考察}

ての公式に從つて，第一表より，一年間に於ける肺炎死亡數の $r_{j}$ 老計算すると次の通りで ある。

。郎ち該當せる日と同じ日とり $r$ は 1 なる事は明かであるから $r_{o}=1$,

$$
\begin{array}{ccc}
r_{1}=0.92 & r_{11}=0.84 & r_{91}=0.12 \\
r_{9}=0.90 & \vdots & \vdots \\
r_{3}=0.88 & r_{16}=0.68 & r_{93}=0.10 \\
r_{4}=0.86 & \vdots & \vdots \\
r_{5}=0.87 & r_{21}=0.76 & \vdots \\
r_{6}=0.87 & \vdots & \vdots \\
r_{7}=0.88 & r_{31}=0.67 & \vdots \\
r_{8}=0.84 & r_{51}=0.48 & \vdots \\
r_{9}=0.86 & \vdots & r_{110}=-0.02 \\
r_{10}=0.86 & r_{71}=0.27 & \vdots \\
& & r_{180}=-0.19
\end{array}
$$

但し $E=0.05$

$r_{j}$ を縱座模にとり折線を描くと第 2 圖の道りである。

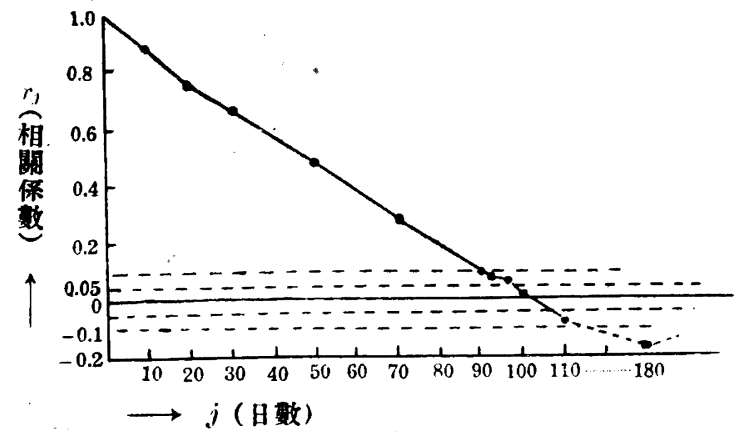

第 2 圖 點線……䛇差の笻園を示す
第2 圖に於いて見られる通り，肺 炎の餘效は非常に大きい事がわか る. 即ち $r_{j}$ は $r_{j}=1$ から $j$ が塯す につれて次第に滑力に $r_{j}=0$ す線に - 向つて接近する.而して $j=96$ から 先は誤宾の範圍內に落ちる。次に $j=100$ は殆んど $r_{j}$ が零に近づき， それより先は負數をとるやをにな る. 今 $r_{j}$ が本均誤著の二倍以上な る時を有意なりとすると $j=90$ まで 
が有意となる・郎ち，肺炎にて今日死亡する人の僌と，それより90日後に肺炎にて死亡する であら5と豫想される人の數上の䦌に相關關係が認められる。從つて肺炎死亡の 餘效は大體 90 日なりと云ふ.事が州來る。

$j=100$ から先に $r_{j}$ が顀數を示すりは，100 日から先になると郝炎の死亡に對し外因が反つ

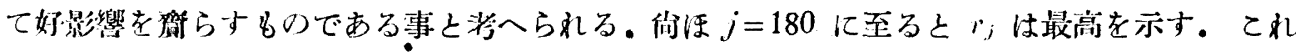
は 180 日が肺炎死亡に對し最も好影響支與へる外团の下にある事を示すもの上考一られる。第

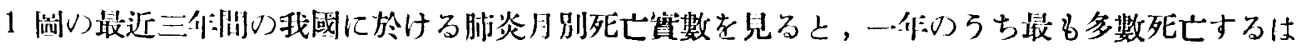

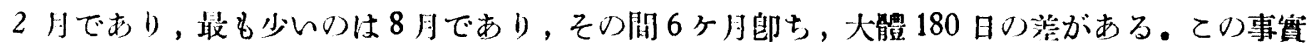

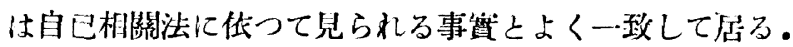

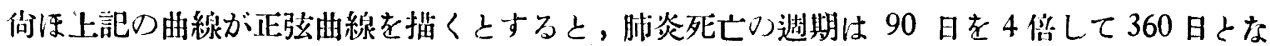

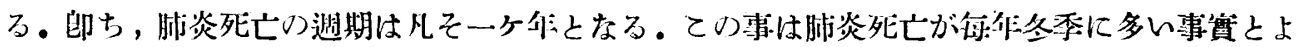
く合致するけである。

以上は一ケ非 366 日の系列の各要絭汇就き ち昭利 14 年 12 月 1 日上り柆作 3 月 31 日まで 122 日間の各姴絭 (第 1 表參照) 几就い て同梯に $r_{j}$ を計算すると次の通りである。

$\begin{array}{llll}r_{0}=1 & r_{3}=0.17 & r_{6}=0.16 & r_{9}=0.02 \\ r_{1}=0.34 & r_{4}=0.08 & r_{7}=0.17 & r_{10}=0.03 \\ r_{2}=0.21 & r_{5}=0.15 & r_{8}=0.07 & r_{11}=-0.05 \\ E=0.09 & & & \end{array}$

今 $r_{j}$ が平均誤参の二倍以上なる時を有意なりとすると相關關係の有意なるは $r_{2}$ までであ る。郎ち，冬季に於んては本日肺炎にて死亡する人の數はその翌日並びに翌々日肺炎にて死亡 すると鲹想される人の數との間に相關關係が認められるのである。而して三日後からは $r_{j}$ は 誤荎の䡉園に落ちるのである。

\section{6. 肺炎死亡數と寒冷前線との關俰}

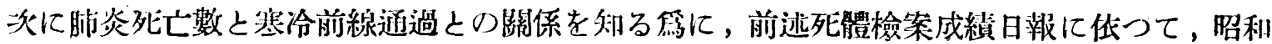
10 胙 12 月 1 日上り昭和 11 作 3 月 31 日まで，昭和 11 作 12 月 1 日上り昭利 12 年 3 月 31 日まで, 昭利 12 作 12 月 1 日より昭和 13 作 3 月 31 日まで, 昭和 14 年 12 月 1 日上り昭和 15 年 3 月 31 日までの冬季四ヶ年合計 486 日に於ける肺炎死亡數を逐日的に調 べた・第 3 表の通りである。 
第 3 表

\begin{tabular}{|c|c|c|c|c|c|c|c|c|c|c|c|c|c|c|c|c|}
\hline 月 & $\begin{array}{c}10 \text { 年 } \\
12\end{array}$ & $\begin{array}{c}11 \text { 年 } \\
1\end{array}$ & ${ }_{2}^{\prime \prime}$ & $\begin{array}{l}\prime \prime \\
3\end{array}$ & $\begin{array}{c}11 \text { 年 } \\
12\end{array}$ & $\begin{array}{c}\text { 12年 } \\
1\end{array}$ & $\begin{array}{l}\prime \prime \\
2\end{array}$ & $\begin{array}{c}\prime \prime \\
3\end{array}$ & $\begin{array}{c}12 \text { 年 } \\
12\end{array}$ & $\begin{array}{c}13 \text { 年 } \\
1\end{array}$ & $\begin{array}{l}\prime \prime \\
2\end{array}$ & $\begin{array}{c}\prime \prime \\
3\end{array}$ & $\begin{array}{c}14 \text { 年 } \\
12\end{array}$ & $\begin{array}{c}15 \text { 年 } \\
1\end{array}$ & 2 & 3 \\
\hline 1 & 30 & 24 & $5 \pi$ & $33 \|$ & 13 & 40 & 47 & 41. & 10 & 40 & 74 & 59 & 36 & 55 & 50 & 44 \\
\hline 2 & 22 & 31 & 68 & 37 & 14 & 38 & 69 & 39 & 14 & $51 \mid$ & 93 & 70 & 24 & 58 & 78 & 52 \\
\hline 3 & $8 T$ & 47 & 65 & 29 & 29 & 42 & 71 & 56 & 23 & 39 & 83 & 71 & 32 & 57 & 52 & 56 \\
\hline 4 & 23 & 33 & 62 & 33 & 18 & 38 & 60 & 32 & 20 & 50 & 76 & $71 \|$ & 40 & 69 & 69 & 60 \\
\hline 5 & 24 & 39 & 68 & 28 & 28 & 33 & 71 & 24 & 20 & 53 & 91 & 55 & 43 & 65 & 60 & 64 \\
\hline 6 & 23 & 30 & 56 & 89 & 17 & 53 & 73 & 40 & 80 & $43 \mid$ & 82 & 57 & 27 & 48 & 43 & 64 \\
\hline 7 & $\therefore 6$ & 33 & 57 & 40 & 19 & 48 & 66 & 26 & 17 & 47 & 78 & 62 & 35 & 59 & 60 & 47 \\
\hline 8 & 28 & 36 & 60 & 36 & 20 & 52 & 64 & 47 & 25 & 40 & 82 & 52 & 35 & 62 & 50 & 4.3 \\
\hline 9 & 20 & 43 & 58 & 31 & 26 & 47 & 6. & 31 & 18 & 65 & 89 & 55 & 41 & 45 & 57 & i) 1 \\
\hline 10 & 23 & 34 & 55 & 36 & 19 & 50 & 70 & 32 & ב & 55 & $8: 31$ & 50 & 47 & 56 & 66 & 37 \\
\hline 11 & 29 & 40 & 51 & St & 19 & 43 & 78 & 40 & 21 & $5 \tilde{5}$ & 78 & 63 & 4.4 & 63 & 55 & 68 \\
\hline 12 & |דב & 39 & 57 & $\therefore 9$ & 21 & 58 & 82 & 22 & 87 & 65 & 79 & 61 & 47 & 73 & 50 & 40 \\
\hline 13 & 31 & $3 i$ & 47 & 43 & 13 & 55 & 64 & 32 & 87 & 76 & $9 \tilde{1}$ & 40 & 50 & 48 & 48 & 50 \\
\hline 14 & 31 & 33 & 41 & $\because 6$ & 1 & 50 & 57 & 33 & 31 & Só & 96 & 50 & 48 & 66 & 45 & 53 \\
\hline 15 & 88 & 35 & 4.5 & 24 & 24 & б1 & 47 & 34 & $\Omega t$ & $8: 3$ & 76 & 42 & 56 & 60 & 73 & 64 \\
\hline 16 & SO & $4 t^{\prime}$ & 48 & $s 0$ & 32 & 60 & 63 & 29 & -3 & 78 & 91 & 50 & 70 & 44 & 59 & 50 \\
\hline 17 & 33 & $44^{\prime}$ & 34 & 26 & $\therefore 9$ & 63 & 51 & 39 & 43 & 82 & 103 & 37 & 70 & $5 \overline{0}$ & 57 & 47 \\
\hline 18 & 93 & $\delta 1$ & 39 & 30 & 33 & $\tilde{5} 9$ & 44 . & 28 & 21 & 75 & 73 & 35 & $\tilde{j} \tilde{0}$ & 45 & 60 & 66 \\
\hline 19 & 19 & 53 & 35 & 31. & 31 & 54 & 53 & 40 & 31 & 74 & 70 & ז7 & 47 & 45 & 48 & 63 \\
\hline 20 & 28 & 55 & $3 \overline{5}$ & 20 & 17 & 48 & 42 & 39 & 30 & 82 & 79 & 37. & 51 & 52 & 43 & 61 \\
\hline 21 & 46 & 68 & 35 & 25 & 17 & 51 & .53 & 46 & 35 & 88 & 73 & 45 & 62 & 59 & 52 & 46 \\
\hline בצב & 35 & 65 & 32 & 36 & $\therefore 4$ & 68 & 45 & 34 & 31 & 74 & 88 & 36 & 66 & 56 & $4 t$ & 4) \\
\hline 23 & 44 & 55 & 39 & 26 & 12 & 79 & 44 & 39 & 39 & 76 & $\neg 1$ & 49 & 66 & 62 & 55 & 41 \\
\hline 84 & 31 & 61 & 32 & $22^{i}$ & 26 & 69 & 66 & 33 & 41 & 77 & 91 & 37 & 62 & 46 & 54 & 42 \\
\hline 95 & 40 & 51 & 36 & 30 & 31 & 50 & 36 & 36 & 30 & 86 & $7 \tilde{T}$ & 33 & 56 & 54 & 55 & 51 \\
\hline 26 & 41 & 72 & 39 & 24 & 29 & 65 & 43 & 27 & 40 & 106 & 94 & 44 & $5 \tilde{5}$ & 55 & 58 & 48 \\
\hline 27 & 32 & 62 & 28 & 31 & 31 & 65 & 40 & 34 & 38 & 74 & 98 & 26 & 63 & 50 & 63 & 66 \\
\hline 28 & 20 & 70 & 36 & 37 & 30 & 61 & 43 & 42 & 46 & 74 & 112 & 37 & 54 & 54 & 67 & 58 \\
\hline 89 & 36 & 68 & $\approx 6$ & 17 & 41 & 77 & - & 44 & 41 & 95 & - & 26 & 55 & 48 & 41 & 49 \\
\hline 30 & 39 & 60 & - & 26 & 44 & 79 & - & 29 & 46 & 96 & - & 24 & 59 & 52 & - & 53 \\
\hline 31 & 21 & 53 & & 27 & 28 & 65 & - & 30 & 39 & 76 & - & 33 & 39 & 49 & - & 41 \\
\hline 計 & 907 & & & 914 & & & & & $893^{\prime}$ & & &, 434 & 1,535 & 710 &, 582 & 1,625 \\
\hline
\end{tabular}

總計 486 日 23,113

次に中央氣象薹發行の『日刊天氣圖』に依つて上記期間中に束京市を著朋なる寒冷前線が通 過せる日及びその大體の時刻と，東京市に著朋なる局所前線が通じたる日及びその大體の時刻 とを調へた。局所前線乙は局所的に突然生ずる不連續線の事で, 束京南附近はその記载が特に 詳しい。余はその著明なるものを探用した。

、『日刊天㴋圖〔は午前 6 時, 千後 6 時の一日二包に，そり現在の氣像状沉を記錄し，それを印 
刷に附し，日ょ發刊せるもので，天氣圖原圖に依つて作製したものである。從つて余は『日刊 天氣圆』に於々て前線通過の時刻の不明膫なる時は, 一日四包郎ち, 6 時, 12 時, 18 時, 24

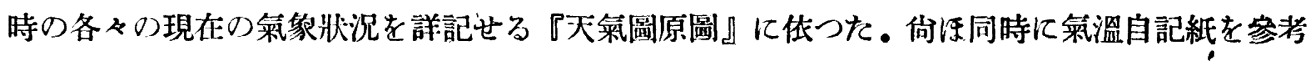
に俶した。

かくして日别脯炎死亡數之然冷前線通過の日とを知り得たので网者老偶然性を除く爲にDüll つ所謂『N啮』(n-methode) に依つて集計した。その絬果は第四表に示寸通りである。

第 4 表は前線の通過せる日を $f$ と名け，前線通過三日前，二日前，一日前をそれぞれ $f-3$, $f-2, f-1$ と名け，通過の翌日，二日後，三日後，をそれぞれ $f+1, f+2, f+3$ と名け，前線 通過の日を中心として前後7日間の各々の日に於ける肺炎死亡数を合計したものである。

第四表に見ら犼る通り，最近四年間の冬季（12月上り翌年 3 月まで）に於ける肺炎死亡數は

\begin{tabular}{|c|c|}
\hline 前線通過の前日 & 6262 人 (本均 48.5 人) \\
\hline 前線通過の當日 & 7185 人（平均 55.7 ) \\
\hline 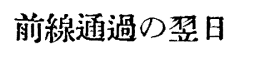 & 人（平均 48.5 \\
\hline 日 & \\
\hline
\end{tabular}

即ち，前線通過の日は肺炎死亡数は他の日に比し著しく堬加してるる事がわかる。

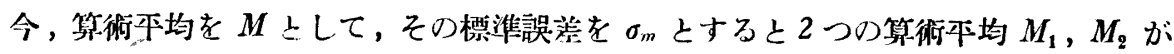

$$
M_{2}-M_{1}>2 \sqrt{\sigma_{m_{1}}{ }^{2}+\sigma_{m 2}{ }^{2}} \text { なるとき }
$$

$M_{2}>M_{1}$ が有意なりと判定が出柬る。

前線通過當日の肺炎死亡數の算術平均老 $M_{f}$ ，前線通過前日のそれを $M_{f-1}$ ，翌日のそれを $M_{f+1}$ ¿L，その各《の標準誤差を夫ぬ $\sigma_{f}, \sigma_{j-1}, \sigma_{f+1}$, とする上

$$
\begin{gathered}
M_{f}-M_{f-1}=55.7-48.5=7.2 \\
\sqrt{\sigma_{f}^{2}+\sigma_{f-1}^{2}}=\sqrt{2.74+2.08}=\sqrt{4.82 \div 2.2}
\end{gathered}
$$

從つて $M_{f}>M_{f-1}$ は有意である. 次に $M_{f}-M_{f+1}=55.7-48.5=7.2$

$$
\sqrt{\sigma_{f}^{2}+\sigma_{f+1}{ }^{2}}=\sqrt{2.74+2.67}=\sqrt{5.41} \div 2.3
$$

從つて $M_{f}>M_{f+1}$ は有意である。

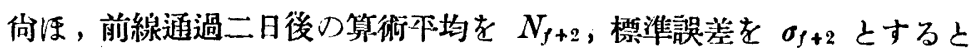

$$
\begin{gathered}
M_{f}-M_{f+2}=55.7-48.1=7.6 \\
\sqrt{\sigma_{f}^{2}+\sigma_{f+2^{2}}}=\sqrt{2.74+2.29}=\sqrt{5.03} \doteqdot 2.2
\end{gathered}
$$

從つて $M_{f}>M_{f+2}$ は有意である。

て々，前線通過三日後の算術本均を $M_{f+3}$, 標淮誤差を $\sigma_{f+3}$ とすると

$$
M_{f}-M_{f+3}=55.7-49.4=6.3
$$


第 4 表

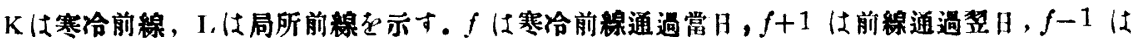
前線通過前日を示寸。

\begin{tabular}{|c|c|c|c|c|c|c|c|c|c|c|c|c|c|c|c|c|}
\hline $\begin{array}{l}\text { 色日並びに } \\
\text { 象 }\end{array}$ & -3 & $f-2$ & -1 & $f$ & $f+1$ & +2 & $f+3$ & & $\begin{array}{r}\text { 並びに } \\
\text { 象 }\end{array}$ & $f-3$ & $f-0$ & $f-1$ & $f$ & $f+1$ & $f+2$ & $f+3$ \\
\hline 昭和10年 & 24 & 23 & 26 & 28 & 20 & 23 & 29 & " & 18日 L & 51 & 60 & 63 & 59 & 54 & 48 & 51 \\
\hline " 17 日 K & 31 & 28 & 29 & 33 & 23 & 19 & 28 & "' & 5 日 K & 68 & 79 & 69 & 70 & 65 & 65 & 61 \\
\hline " 21 日 K & 23 & 19 & 28 & 46 & 35 & 44 & 31 & $" \prime$ & 29 日。 & 65 & 65 & 61 & 77 & 79 & 65 & 47 \\
\hline " 29 月 K & 41 & 32 & 25 & 36 & 39 & 81 & 24 & $"$ & 30 日 r. & 65 & 61 & 77 & 79 & 65 & 47 & 69 \\
\hline${ }^{\prime \prime} \quad 30$ 日 K & 32 & 25 & 36 & 39 & 21 & 24 & 34 & 2) & 月 2 日 $\mathrm{L}$, & 79 & 65 & 47 & 69 & 71 & 60 & 71 \\
\hline $\begin{array}{l}\text { 昭和 } 11 \text { 年 } \\
1 \text { 月 } 5 \text { 日 }\end{array}$ & 34 & 47 & 33 & 39 & 30 & 33 & 36 & " & 3 日 $\mathrm{I}$ & 65 & 47 & 69 & 71 & 60 & 71 & 73 \\
\hline " 9 日 & 30 & 33 & 36 & 43 & 34 & 40 & 39 & "I & 5日 K & 69 & 71 & 60 & 71 & 73 & 66 & 64 \\
\hline " 17 日 K & 33 & 35 & 44 & 44 & 51 & 53 & 55 & $" 1$ & 6 日 $\mathrm{K}$ & 71 & 60 & 71 & 73 & 66 & 64. & 62 \\
\hline " 18 日 $\mathrm{K}$ & 35 & 44 & 44 & 51 & 53 & 55 & 68 & $\prime \prime$ & 10日 L & 66 & 64 & 62 & ro & 78 & 82 & 64 \\
\hline " 20 日 K & 44 & 51 & 53 & 55 & 68 & 65 & 55 & $\prime \prime$ & 日 $\mathrm{K}$ & 64 & 72 & 79 & 78 & 82 & 64 & 57 \\
\hline " 21 日 K & 51 & 53 & 55 & 68 & 65 & 55 & 61 & " & 12 日 & 62 & 70 & 78 & 82 & 64 & 57 & 47 \\
\hline " 26 日 $\mathrm{K}$ & 55 & 61 & 51 & 72 & 62 & $7:$ & 68 & $\prime \prime$ & 19日 & 63 & 51 & 44 & 53 & 48 & 53 & 45 \\
\hline " 28 日 I。 & 51 & 72 & 62 & 72 & 68 & 60 & 53 & $\prime \prime$ & 21 日 K & 44 & 53 & 42 & 53 & 45 & 44. & $60^{\circ}$ \\
\hline 2 月 7 日 & 62 & 68 & 56 & 57 & 60 & 58 & 55 & $"$ & 24 日 K & 53 & 45 & 44. & 66 & 36 & 43 & 40 \\
\hline " 15 日 L & 57 & 4.7 & 41 & 45 & 42 & $\varepsilon$ & 39 & $\prime \prime$ & 26 日 L。 & 44 & 66 & 36 & 43 & 40 & 43 & 41 \\
\hline " 23 日. & 35 & 35 & 32 & 39 & 32 & 36 & 39 & $\prime \prime$ & 27 日 K & 66 & 36 & 43 & 40 & 43 & 41 & 39 \\
\hline " 25 日 L & 32 & 39 & 38 & 36 & 39 & $2 \varepsilon$ & 36 & 3 ) & 月 3 日 $\mathrm{K}$ & 43 & 41 & 39 & 56 & 32 & $2 t$ & 40 \\
\hline$" 28$ 日 & 36 & 39 & 28 & 36 & 26 & 3 & 29 & $\prime \prime$ & 6 日 $\mathrm{K}$ & 56 & 32 & 24 & 40 & 26 & +15 & 31 \\
\hline 3 月 2 日 I & 36 & 26 & 33 & 37 & 29 & 3 & 28 & $\prime \prime$ & 8 日 & 24 & 40 & -26 & 47 & 31 & 33 & 40 \\
\hline$"$ " 7 日 K & 33 & 28 & 29 & 40 & 36 & 3 & 36 & $\prime \prime$ & 11 日 $\mathrm{K}$ & 47 & 31 & 32 & 40 & 28 & 32 & 33 \\
\hline " 10 日 L & 40 & 36 & 31 & 36 & 27 & 2 & 43 & $\prime \prime$ & 14 日 I & 40 & 22 & 32 & 33 & 34 & 29 & 39 \\
\hline " 13 日 $\mathbf{K}$ & 36 & 27 & 29 & 43 & 26 & 2 & 20 & " & 19 日 $\mathrm{I}$. & 29 & 39 & 28 & 40 & 39 & 46 & 34 \\
\hline " $18 \mathrm{~g} \mathrm{~K}$ & 24 & 80 & 26 & 30 & 31 & 8 & 25 & " & 20 日五。 & 39 & 28 & 40 & 39 & 46 & 34 & 30 \\
\hline " 25 日 L & 36 & 26 & 22 & 30 & 24 & 31 & 37 & " & 21 日 L & 28 & 40 & 39 & 46 & 34 & 32 & 33 \\
\hline " 28 日 I & 30 & 24 & 31 & 37 & 17 & 2 & 27 & $\prime \prime$ & 25 日 I, & 34 & 32 & 33 & 36 & 27 & 34 & 42 \\
\hline $\begin{array}{l}\text { 昭和11年 } \\
12 \text { 月 } 12 \text { 日 }\end{array}$ & 26 & 19 & 19 & 21 & 13 & 2 & 84 & $" \prime$ & & 36 & 27 & 34 & 42 & 44 & 89 & 30 \\
\hline " 18 日 & 24 & 32 & 29 & 33 & 31 & $1^{\prime}$ & 17 & & 29 日 K & 87 & 34 & 42 & 44 & 29 & 30 & 41 \\
\hline " 30 日 I & 31 & -30 & 41 & 44 & 28 & 4 & 38 & $\begin{array}{l}\text { 昭 } \\
12\end{array}$ & 和 1 & 10 & 14 & 33 & 20 & 20 & ב0 & 17 \\
\hline $\begin{array}{l}\text { 昭和 } 12 \text { 年 } \\
1 \text { 月 } 6 \text { 日 }\end{array}$ & 42 & 38 & 33 & 53 & 48 & 5 & 47 & "1 & $10 \mathrm{E} \mathbf{I}$ & 17 & 25 & 18 & 22 & 21 & 27 & 27 \\
\hline "7捍 & 38 & 33 & 53 & 48 & 52 & 4 & 50 & " & $12 \mathrm{H} \mathrm{K}$ & 18 & 28 & 91 & 27 & 87 & 31 & 2 \\
\hline 8 日 $\mathrm{L}$, & 33 & 53 & 48 & 52 & 47 & 5 & 45 & " & & 21 & 27 & 27 & 31 & $\therefore t$ & 23 & 43 \\
\hline " 16 日 $\mathrm{I}$. & 55 & 50 & 51 & 60 & 63 & 5 & 54 & 11 & 19日 K & 33 & 43 & 21 & 31 & 30 & 35 & 31 \\
\hline " $17 \mathrm{HI}$ & 50 & 51 & 60 & 63 & 59 & 5 & 48 & $\prime \prime$ & $21 \mathrm{H} \mathrm{K}$ & 21 & 31 & 30 & 35 & 31 & 39 & 41 \\
\hline
\end{tabular}




\section{第 4 表 (續き)}

\begin{tabular}{|c|c|c|c|c|c|c|c|c|c|c|c|c|c|c|c|}
\hline 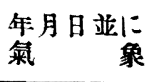 & & & $f-1$ & $f$ & $f+1$ & $f+2$ & $f+3$ & $\begin{array}{l}\text { 年月日並に } \\
\text { 氣 象 }\end{array}$ & $f-3$ & $f-2$ & $f-1$ & $f$ & $f+1$ & $f+2$ & $f+3$ \\
\hline $\begin{array}{l}\text { 照和12年 } \\
12 \text { 月 }\end{array}$ & 35 & 31 & 39 & 41 & 30 & 40 & 38 & " 29 日 K & 55 & 63 & 54 & 55 & 59 & 39 & 55 \\
\hline " 26 日 & 39 & 41 & 30 & 40 & 38 & 46 & $41 \|$ & 昭和 1 & $5 \overline{5}$ & 58 & 57 & 69 & 65 & 48 & 59 \\
\hline $\begin{array}{c}\text { 昭和13年 } \\
1 \text { 月 } 2 \text { 日 }\end{array}$ & 46 & 39 & 40 & 51 & 39 & 50 & 53 & " 5 日 $\mathrm{K}$ & 58 & 57 & 69 & 65 & 48 & 59 & 62 \\
\hline$" \quad 5 \mathrm{HK}$ & 51 & 39 & 50 & 53 & 43 & 47 & 40 & " 8 日 K & 65 & 48 & 59 & 68 & 45 & 56 & 63 \\
\hline$" 7 \mathrm{HI}$ & 50 & 53 & 43 & 47 & 40 & 65 & 55 & $" 12$ 日 K & 45 & 56 & 63 & 73 & 48 & 66 & 60 \\
\hline " 13 日 $\mathrm{L}$ & 55 & 35 & $65 !$ & 76 & 85 & 83 & 78 & " 14 日 K & 63 & 73 & 48 & 66 & 60 & 44 & 55 \\
\hline " 14 日 $\mathrm{K}$ & 55 & 65 & 76 & 85 & 83 & 78 & 82 & " 15 日 K & 73 & 48 & 66 & 60 & 44 & 55 & 45 \\
\hline " 15 日 K & 65 & 76 & 85 & 83 & $7 s$ & 82 & 75 & " $17 \mathrm{H} \mathrm{K}$ & 66 & 60 & $4 t$ & 55 & $45^{i}$ & 45 & 52 \\
\hline " 18 日. K & 83 & 78 & 82 & 75 & 74 & 82 & 88 & " 23 日 K & 52 & 59 & 56 & 62 & 46 & -54 & 65 \\
\hline " $21 月 \mathrm{~L}$ & 75 & 74 & $8:$ & 88 & 74 & 76 & 77 & " 30 日 K & 50 & 54 & 48 & 52 & 49 & 50 & 72 \\
\hline " 25 日 K & 74 & 76 & $7 i$ & 86 & 106 & 74 & 74 & 2月 2日 $\mathrm{K}$ & 52 & 49 & 50 & 72 & 52 & 69 & 60 \\
\hline " 26 月 $\mathrm{K}$ & 76 & $7 \pi$ & 86 & $10 b$ & 74 & 74 & 95 & " 10 日 L & 60 & 50 & 57 & 66 & 55 & 50 & 48 \\
\hline " 30 日 I & 74 & $7 t$ & 95 & 96 & 76 & 74 & 93 & " 15 日 L & 50 & 48 & $4 \overline{0}$ & 73 & 59 & 57 & 60 \\
\hline$\therefore$ 月 5 日 $\mathrm{K}$ & 93 & 83 & 76 & 91 & 82 & 78 & 82 & " 19 日 K & 59 & 57 & 60 & 48 & 43 & 58 & 44 \\
\hline " 8 月 $\mathrm{K}$ & 91 & 82 & 78 & 82 & 89 & 83 & 77 & " 21 月L & 60 & 48 & 43 & 52 & 44 & $55^{-1}$ & 54 \\
\hline " 14 日 K & 77 & 79 & 95 & 96 & 76 & 91 & 103 & " & 44 & 55 & 54 & 55 & 34 & 63 & $6 i$ \\
\hline " 17 日 K & 96 & 76 & 91 & 103 & 73 & 70 & 79 & " 28 日 K & 55 & 34 & 63 & $6 i$ & 41 & 44 & 52 \\
\hline " 24 日 K & 73 & 88 & 71 & 91 & 75 & 94 & 98 & 3 月 4 日 K & 44 & 52 & 56 & 60 & 64 & 64 & 47 \\
\hline " 28 日 K & 75 & 94 & 98 & 112 & 59 & 70 & 71 & " 5 日 $\mathrm{K}$ & 56 & 56 & 60 & 64 & 64 & 47 & 43 \\
\hline $\begin{array}{l}\text { 昭和 } 13 \text { 年 } \\
3 \text { 月 } \\
\text { 日 } \mathrm{K}\end{array}$ & 98 & 112 & 59 & 70 & 71 & 71 & 55 & " 6 日 I & 56 & 60 & 64 & 64 & 47 & 43 & 51 \\
\hline 3 日 $\mathrm{K}$ & 112 & 59 & 70 & 71 & 71 & 55 & 57 & " 11 日 $\mathrm{K}$ & 43 & 51 & 37 & 68 & 42 & 55 & 53 \\
\hline " 6 日 $\mathrm{K}$ & 71 & 71 & 55 & 57 & 62 & 52 & 55 & " 15 日 K & 42 & 55 & 53 & 64 & 50 & 47 & 66 \\
\hline " 11 日 L & 52 & 55 & 50 & 63 & 61 & 40 & 50 & " 18 日 L & 64 & 50 & 47 & 66 & 63 & 61 & 46 \\
\hline " 23 日 L & 37 & 45 & 36 & 49 & 37 & 33 & 44 & " 19 日 K & 50 & 47 & 66 & 63 & 61 & 46 & 40 \\
\hline " 26 日 K & 49 & 37 & 33 & 44 & 26 & 37 & 26 & " 20 日 K & 47 & 66 & 63 & 61 & 46 & 40 & 41 \\
\hline " 28 日 L & 33 & 44 & 26 & 37 & 26 & 24 & 33 & " 21 日 K & 66 & 63 & 61 & 46 & 40 & 41 & 42 \\
\hline$" \prime 31$ 日 K & 37 & 26 & 24 & 33 & 24 & 30 & 24 & " 27 日 K & 42 & 51 & 48 & $66 !$ & 58 & 49 & 53 \\
\hline $\begin{array}{l}\text { 照和14年 } \\
12 \text { 1日 } \\
\text { " } 3 \text { 的 }\end{array}$ & $\begin{array}{l}24 \\
25\end{array}$ & $\begin{array}{l}38 \\
36\end{array}$ & $\begin{array}{l}25 \\
24\end{array}$ & $\begin{array}{l}36 \\
32\end{array}$ & $\begin{array}{l}24 \\
40\end{array}$ & $\begin{array}{l}32 \\
43\end{array}$ & $\begin{array}{l}40 \\
27\end{array}$ & " 30 日 K & 66 & 58 & 49 & 53 & 44 & 48 & -55 \\
\hline 4 日 L & 36 & 24 & 32 & 40 & 43 & 27 & 35 & 計 129 日 & 6369 & 6329 & 6262 & 7185 & .6254 & 6211 & 6373 \\
\hline $9 \mathrm{HI}$ & .27 & 35 & 35 & 41 & 47 & 44 & 47 & 平均 (M) & 49.4 & 49.1 & 48.5 & 55.7 & 48,5 & 4 & 49.4 \\
\hline " 10 日 K & 35 & 35 & 41 & 47 & 44 & 47 & 50 & & & & & & & & \\
\hline " 16 月 K & 50 & 48 & 56 & 70 & 70 & 55 & 47 & & & & & & & & \\
\hline " 27 日 L & 62 & 56 & 55 & 63 & 54 & 55 & 59 & $\sqrt{n}$ & & & & & & & \\
\hline " 28 日 K & 56 & 55 & 63 & 54 & 55 & 59 & 39 & & & & & & & & \\
\hline
\end{tabular}


$\sqrt{\sigma_{f}{ }^{2}+\sigma_{f+3}{ }^{2}} \div 2.3$ 從つて $M_{f}>M_{f+3}$ は有意, 前線通過二日前の算術平均を $M_{f-2}$, 三日前 老 $M_{f-3}$ とし, 標準誤差を夫そ $\sigma_{f-2}, \sigma_{f-3}$ とすると

$$
\begin{gathered}
M_{f}-M_{f-2}=55.7-49.1=6.6 \\
\sqrt{\sigma_{f}^{2}+\sigma_{f-2}^{2}}=\sqrt{ } 2.74+2.53 \div 2.3
\end{gathered}
$$

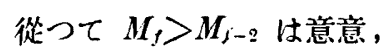

$$
\begin{gathered}
M_{f}-M_{f-3}=55.7-49.4=6.3 \\
\sqrt{\sigma_{f}^{2}+\sigma_{f-3}{ }^{2}}=\sqrt{2.74+2.72} \div 2.3
\end{gathered}
$$

從つて $M_{f}>M_{f-3}$ は有意である。

以上に依つて，前線通過當日の肺炎死亡數は他の日上り有意の差があると云ふ事が州來る・* 次に Jelinek は腦溢血發作と氣像との關係省見る時, 觀察せる日 $\mathrm{t}$ 日間に著明なる氣象の 變化ありし、が $v$ 日ありとすれば，

$\frac{v}{t} 100=p \%$ と

この $t$ 日間の症例を $K$ とし，氣象變化ありし日の症例を $K^{\prime}$ とれば $\frac{K^{\prime}}{K} 100=q \%$ なり $\varepsilon し$,

i） $q$ が $p$ より著しく大ならば氣象の影響は陽性，

ii) $q$ が $p$ 亿近似值ならば氣象の影響はなく，

iii） $q$ が $p$ より著しく小ならば氣像の影響は反つて阻止的なり之稃してみる。

この方法に依ると, 余が能察した前述最近四ケ年の冬季（12 月上り翌年 3 月まで合計 486

日）に前線の通過せる日は第 4 表に明かな如く 129 日なる故

$$
p=\frac{129}{486} \times 100=26.54 \%
$$

又, 第 3 表並びに第 4 表に依つて, 上記期間中の肺炎死亡總嫩は 23,113 人にして，前線 通過當日の死亡總數は 7185 人なる故，

$$
\text { * } q=\frac{7185}{23.113} \times 100=31.09 \% \text { なり。 }
$$

$p$ の標準誤差を $\sigma_{j}, q$ のそれを $\sigma_{q}$ とすると公式

$$
\begin{aligned}
& \sigma_{\rho}=\sqrt{\frac{p(100-p)}{n}} \text { て依り } \\
& \sigma_{p} \doteqdot \sqrt{4.01}, \sigma_{1} \div \sqrt{0.09} \text { なり. }
\end{aligned}
$$

差の標準誤差を $\sigma_{p}$ とすれば

$$
\sigma_{D}=\sqrt{\sigma_{\rho}^{2}+\sigma_{\eta}{ }^{2}} K L \tau
$$

$q \div p>2 \sigma_{D}$ ならば $q>p$ なる事は有意なりと制定が出來る。 
$\sigma_{D}$ を求めると $\sigma_{D} \doteqdot \sqrt{4.01+0.09} \div 2.03$

然るに $q-p=31.09-26.54=4.55$

從つて $q-p>2 \sigma_{D}$

故に $q>p$ は有意であ己。

從つて此の方法に依るも肺炎死亡發生に對して, 前線通過流影響あり之云ふ事が州爽る。

\section{7. 肺炎死亡數特に多き日の氣象並にその飛躍度に就いて}

前節に於々て，寒冷前線通過虽日の肺炎死亡數は他の日に此し增加与万傾向にあり，その閑 に有意の养のある事を述べなが，本節に於いては肺炎死亡數が特に多き月の 2,3 を遙び，その

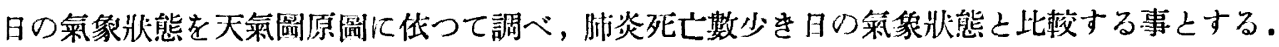

巨第 1 例了昭和 15 年 1 月 12 日には 18 時より 24 時の閒に然渝前線が通過してなるが， その日の肺淡死亡数はその前後の日に比し落しく城加してるう。今 1 月 11 日 6 時より 1 月

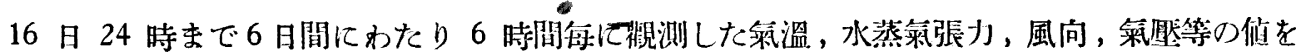
天氣圖原圖第 2 圖に低つて水めると第 5 表の通りである。

さて，氣溫は必ずしも寒暖つ體感とは一致しない，風速の大小，濕度の高低は勿論，日射の 有鮥强弱が著しく體感を左右する。體感を军溫や濕度等の函數として表はさうとして相當溫度

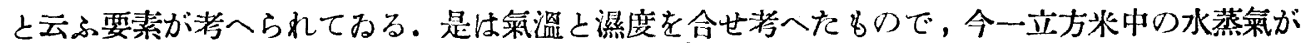
全部凝結し，その潜熱が全部，現に溫度 $t$ 度の乾燥空㴋を $L t$ 丈け景溫せしむるに消費された とすると，相當溫度 $A$ は

$$
\text { ( } A=t+\Delta t \text { と定義する) }
$$

$$
\begin{aligned}
& A=t+\frac{e(606.5+0.305 t)(273+t)}{0.2375 \times 1000 \times 1.293 \times 273 b}
\end{aligned}
$$

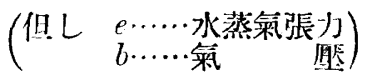

であるが，近似的には

$$
A=t+2 e \text { として十分である。 }
$$

之が所謂高度補亚を施したるPrött の相當溫度の公式である・之を $t_{p}$ と畺くと

$$
t_{n}=t+2 e \text { である。 }
$$

第 5 表の資料に基き前記 1 月 11 日より 1 月 16 日に至る間の 6 時間每に测定した相當溫度 $(t)$ を求めると第 5 表に記した通りである。次に環境の變化の程度を知る一手段として或る 時刻に测定せる相當溫度の值から，そのすぐ前の時刻に测定せる相賞溫度の值を引んて（この

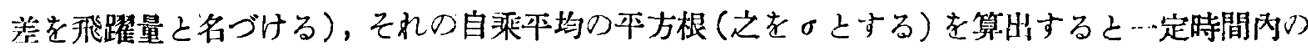
相當溫度の平均の飛躍の速さが求められる.そこでこの $\sigma$ 孛飛躍度と名づける. 即ち，6 時間 
第 5 㤗

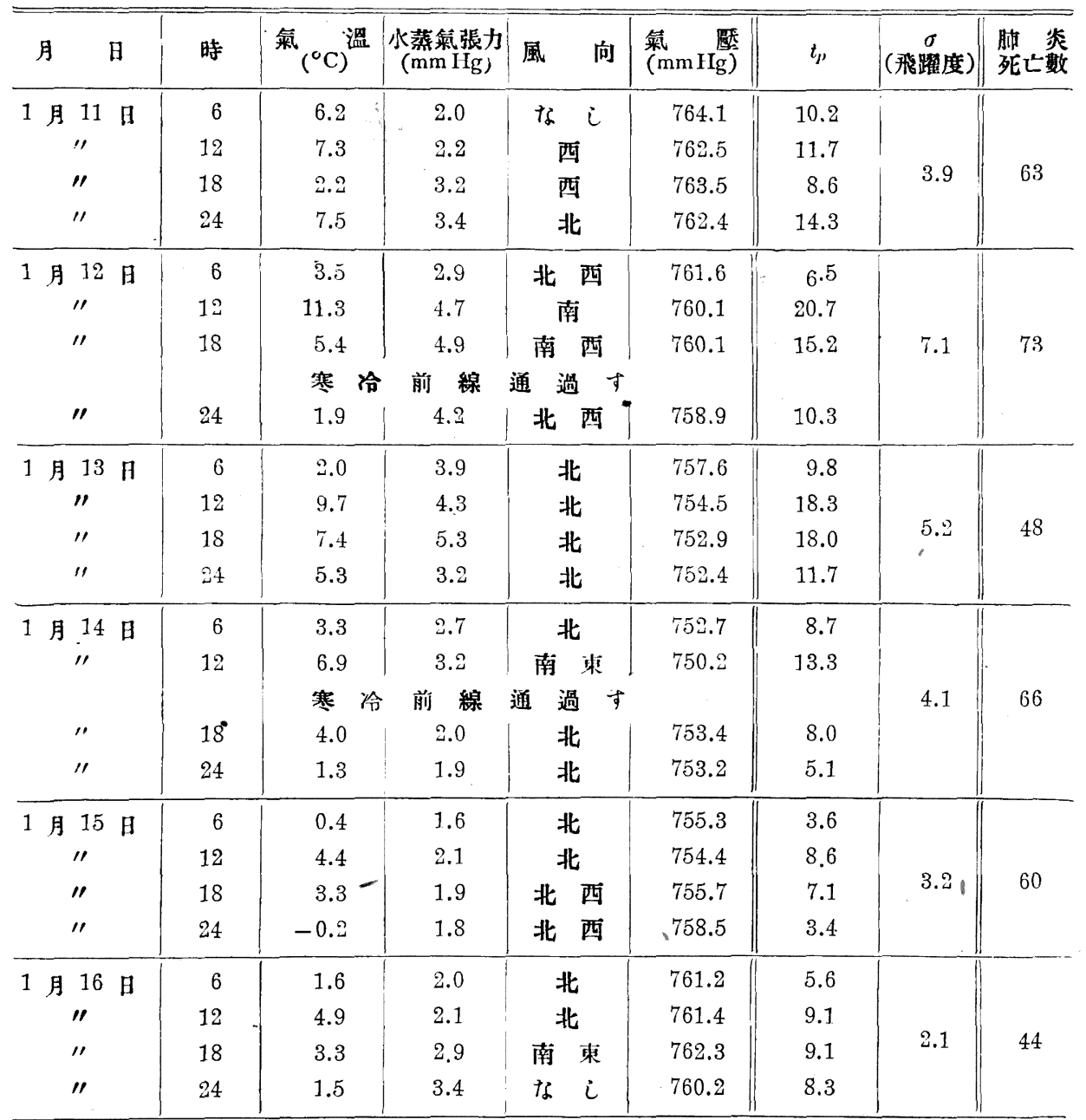

每に测定せる相當溫度の一つの值と，そのすぐ前の值との竧を $\Delta t_{p}$ とすれば一日四包测定せる を以て

$$
\begin{aligned}
& \sigma=\sqrt{\frac{\sum\left(\Delta t_{p}\right)^{2}}{4}} \\
& \Delta t_{p}=t_{p}(i-6)-t_{p}(i)
\end{aligned}
$$

$t_{p}(i) \cdots \cdots$ ある時刻 $t$ における Prött の相當溫度

而してての飛躍度のの小さん事は氣塊の交替又は變質の度の小さん事を示すものと見做し得 る.

そてで第 5 表の資料に基き，1月11 日より 1 月 16 日に至る 6 日間の各及の日の $\sigma$ を求 めると第 5 表に記した通りであり，寒冷前線通過し，肺炎死亡數著しく增加せる 1 月 12 日は 
そり近傍の日洋し飛躍度も例大なる值をとり，氣塊交替又は變質の度の大なる事を知るので ある。

〔第2 例〕昭和 15 年 2 月 2 日は 18 時上り 24 時の間に寒冾前線が通過してねるが, 肺 炎死亡數も當日はその近傍の日に比し著しく塒加してるる。第 1 例に於レてなしたる上全く同

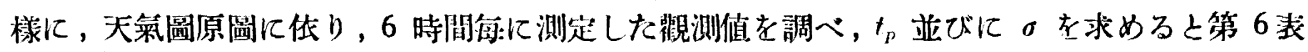
の通りである。

第6表に於々て明かなる通り，2月2日はその近傍の日に對して特に肺炎死亡數多き日であ るが算出せる。 も近傍の日ののに比し大第 6 表にして，氣塊交替の度の大なる事が若へられ るいである。

第 6 表

\begin{tabular}{|c|c|c|c|c|c|c|c|c|}
\hline 月 & 時 & 氣 $\left.{ }^{\circ}{ }^{\circ} \mathrm{C}\right)^{\text {溫 }}$ & $\begin{array}{l}\text { 水蒸氣钱力 } \\
\text { (mm lig) }\end{array}$ & 風 向 & $\begin{array}{l}\text { 氣 厴 } \\
\text { (mmItg) }\end{array}$ & $t_{p}$ & $\sigma$ & 肺䈁 \\
\hline 巳月 1 日 & 6 & 1.2 & 2.8 & 北 西 & 765.6 & 6.8 & \multirow{4}{*}{1.5} & \multirow{4}{*}{50} \\
\hline " & 12 & 3.8 & 2.6 & 北 & 764.5 & 9.0 & & \\
\hline " & 18 & 4.3 & 2.1 & な $i$ & 764.5 & 8.5 & & \\
\hline$" \prime$ & 24 & 1.7 & 2.8 & 北 東 & 765.5 & 7.3 & & \\
\hline \multirow{4}{*}{$\begin{array}{c}2 \text { 月 } 2 \text { 日 } \\
\text { " } \\
\text { " }\end{array}$} & 6 & 0.2 & $\quad 8.1$ & な $i$ & 765.5 & $4.4^{\circ}$ & \multirow{5}{*}{4.0} & \multirow{5}{*}{72} \\
\hline & 12 & 5.7 & 2.9 & 北 & 764.0 & 11.5 & & \\
\hline & 18 & 3.4 & 4.3 & 北 西 & 761.7 & 12.0 & & \\
\hline & 寒 冾 & 前 線 & 過 寸 & & & & & \\
\hline$" 1$ & 24 & 0.7 & 4.5 & 北 & 757.7 & 9.7 & & \\
\hline \multirow{4}{*}{$\begin{array}{c}2 \text { 月 } 3 \text { 日 } \\
\text { " }\end{array}$} & 6 & 0.9 & 4.6 & 北々西 & 752.8 & 10.1 & \multirow{4}{*}{2.9} & \multirow{4}{*}{52} \\
\hline & 12 & 4.9 & 4.3 & " & 752.8 & 13.5 & & \\
\hline & 18 & 4.8 & 2.9 & 北 & 754.4 & 10.6 & & \\
\hline & 24 & 1.9 & 2.5 & 北 西 & 755.5 & 6.9 & & \\
\hline
\end{tabular}

\section{第3章 總括並びに考案}

\section{1. 總括}

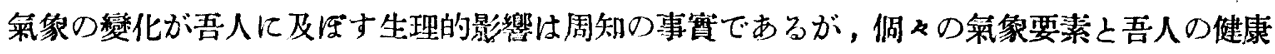
狀感とを關係づけんとする試みは多數の人に依つて行はれたが何れも滿足すべき結果を見るに 至らなかつた。然るに de Rudder が綜合した氣像を表はす『氣塊』を探り上げて，多數の笑 病と氣塊之の關係索組織的に研究し，氣塊の影響の大なる事索認めて以來，多數つ學者の支持 老得て，氣塊の影響は穛認された。我國に於いては既に祄原が喘息發作之氣塊之の關係，星野 が喀血發作と氣塊との關係を迌へてみるが, de Rudder が氣塊との關係最も密接なものの一つ として擧げた肺炎に就いては, 觀察した者は宑闒にして無いと信ずる。 


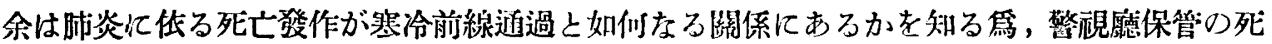

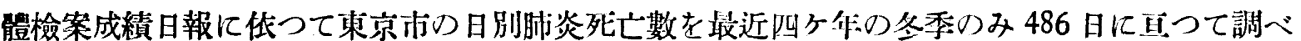

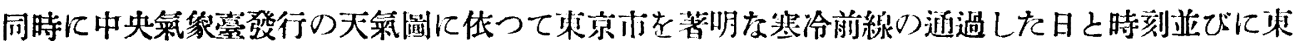
京市に著明なる局所前線の通じたる日と時刻とを知り，兩者を $N$ 法に依つて集計した結果は，

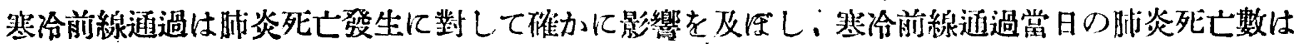
他の日よりも多く，その間に有意の差のある事を知つたのである。

從つて肺炎死亡は集團發生をなし，寒冷前線逝過の當日は塯加する傾向にあると云ひ得るの である。

Konrad Büttner は生物氣候學 (Bioklimatologie) なる一分科索興し，研究け對䀧として 1)

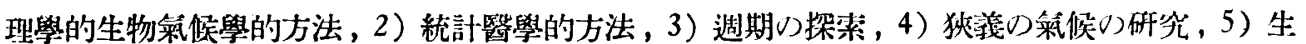
物氣候學的施設の爲の氣瑶研究，の五つを舉げてわる。

余は之に倣つて更に週期の探菜をなすへく昭和 14 年 11 月 1 日上り昭利 15 年 10 月 31 日まで一年間に於ける東京市り日別肺炎死亡數に低つて自己相關法を用ひて肺炎死亡發生り餘 效を求めたる所大䯣 90 日なる事を知つたりである。侣ほ，180 日師ち6ヶ月後は最も好影響 を及殒す外因の下にある事になり，最近 3 ケ作の)我國月別肺炎死亡實数に徽するに，2 月に最 も多く，8月に最も少くして，そい間に6ケ月ひ差りある事望とよく合玟し，從つて 90 日を 4 倍すれば 360 日郎ち大體一ーケ年の週期となり事貫と上く合致する事を知つたりである。

次に系列を冬季のみに上り，昭利 14 年 12 月 1 日上り昭利 15 作 3 月 31 日迄つ 122 日

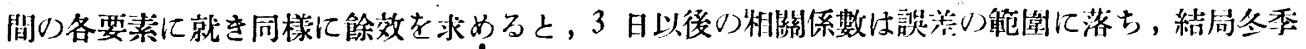
に於ける肺炎死亡の餘效は 2 日と云ふ事になる。

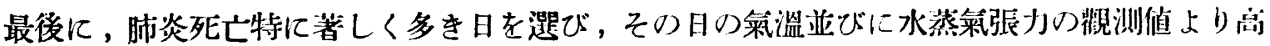

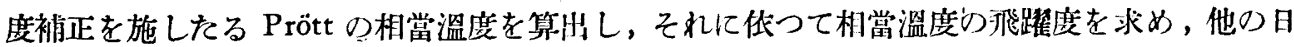
と比較せるに，肺炎死亡數の著しく多き日の飛躍度は他の日の飛躍度に比し著しく大にして， 肺炎死亡數の著しく多き日は氣塊り交代又は變質の度も亦漖しく大なる事を知つたりである。

\section{2. 考按}

次に前線通過が催病的比㗢く原因に就き諸家の知見を見るに， de Rudder は氣筑振動，超短 波並びに空中イオン證の變化等を舉げ Schörer は空中イオンの作用に歸し，Pressat, Cla ude は 前線通過の際，空中笔氣の變化が交感神經を刺激して血清蛍白の平衡障害を來すと云ひ，R. Klotz は天氣過敏症の本態は內分泌機能障害の結果なりと云ひ，Kühnau は空中イオンの戀動 几依つてまてる電磁氣波が影響を及瓜すと述へ，Dorno は同㥞，電磁氣波を皮膚が感受して 知覺神經が刺钱され，更に植物神縃系のトーヌスを變調する結果，之に支配されてるる諸器官 の機能も變化すると說明してるる。然し义, 實際起り得る程度ひ大菊電場つ變化や空中イオン 


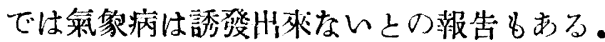

\section{第4章 結 語}

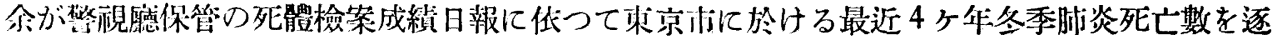
日的に調べたるに，肺炎死亡は集國發生をなし，中央氣像喜發行の天氣圖に依つて寒椧前線通

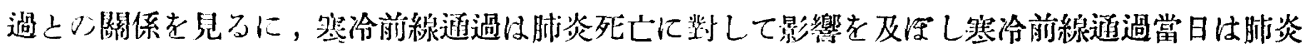
死亡数は塯加与る傾向にあり，殊に氣塊の交替又は變質の度が大なれば肺炎死亡數は著しく㙁 加する傾向にある事を知り得たのである。

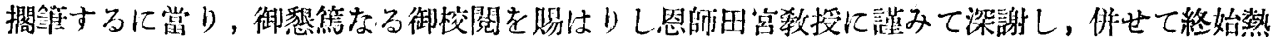

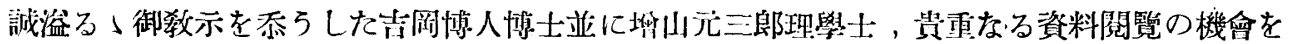

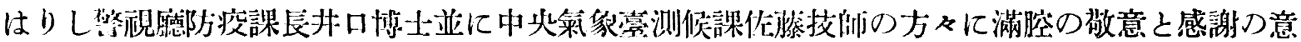
を表す。

\section{資料並びに文獻}

资料

1. 死體檢案成績日報(炤和 10 年より詔和 15 年に二至乃)

2. 日刊天氣圖並に天氣圆原圖

\section{交㩆}

I. 莱像學江關するもの

岡田武松: 氣象學 (照和 2 年).

岡田武松：氣象學整石（昭和12 年).

岡田武松：氣候學（昭和 13 年）。

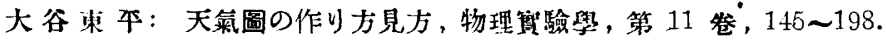

㙁山元三郎：衞生氣象學の現狀 科學 9(1930) 第一號 (別刷).

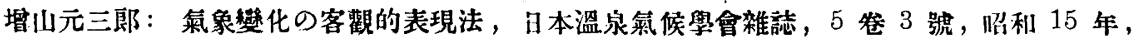
$10 \sim 18$.

增山元三郎：死亡数日督化の調查。

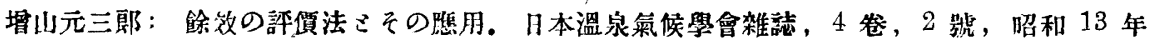
$128 \sim 146$.

荒川秀俊：氣塊諭に關寸万最近の知見，日本溫泉氣候學會雜㛙，2 號，炤和 11 年， $1 \sim 3$.

荒川秀俊: 一日本附近に於け万各氣塊の特性, 氣象集誌, 14 卷 7 號, 第 2 輯, $328 \sim 338$.

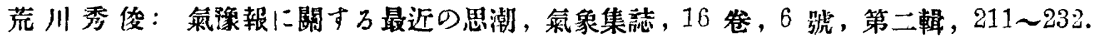

荒川秀俊：氣象力學，炤和 15 年。

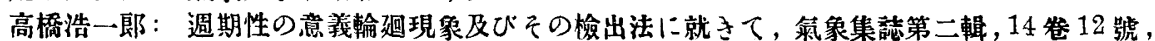
$592 \sim 599$,

高橋浩一郎：振動體の不規則な万運動より，その週期性並に，減衰率を求も万方法に就子 了，理化學研究所急報，第 14 輯，255.

Linke, F. : Meteorologisches, Heilquellen und Heilklima, 1934, 79 103.

Weickmann: Grundlagen der Klima-und Wetterkunde, Klima, Wetter, Mensch. 1938, 6〜126.

- II. 氣像病, 感冒其の他關するもの

de Rudder,: Weteer ". Jahreszeit als Krankheitsfaktoren, Grundriss eiver Meteoropathologie, 1931. 
de Rudder,: Grundriss einer Meteoroliologie des Menschen, 1938,

de Rudder,: Atmosphäre u. Krankheit-Eutwurf einer allgemeinen Meteoropathologie, Kli. W. 19:9, Nr 49, $2365 \sim 2870$.

de Rudder,: Grundzüge der Bioklimatik der Menschen, Wetter, Klima, Mensch. 1938. 127 229.

Flach, Emil: Meteorogisc'1-physikahiche Probleme der Meteuropathologie, Kl. W. 1934, Nr 5, 181 187.

W. Rimpau, : Das Grippeproblem in unserer Zeit, M. M. W, Nr 45, 1937, 1761 1.765.

Ernst, Edens: Ueber Erkältung u. Erkältungskrankheiten, M. M. W, Nr 2, 1938, 41 44.

Weber, A. : Ueber Eakältung u. Erkältumgs Krankehiten, M. M. W, Nr 16, 1938, 588 588.

Flach, E. : Das klimatischen Verhältnisse in Deutschland und die Abhaltung von Sommerla- gern der Hitler-Jugend, M. M. W, Nr 25 , 1938, 947 95.'.

W. Pfanner, : Föhn und Föhnkrankheit, M. M. W. Nr 31, 1939, 1190-1192.

Bauer, Jakol,: Grippe u. Welter, Zeitschrift für K. M, 134 ID, 6 H. 1938, T78 816,

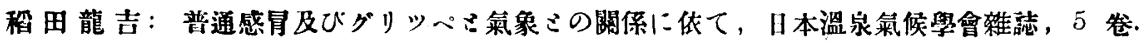
號, 炤利 14 年 $1 \sim 7$.

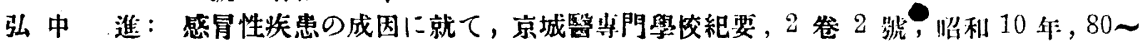
89.

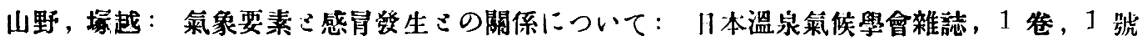
昭利 18年, 168〜177.

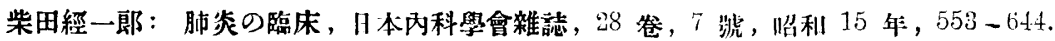

柏井他六郎：氣候馴化の一考察, 國民衞生, 17 卷, 7.8 號, 517〜609.

川人定男: 滿洲に於け万氣侯き聅病に關す万統計學的研究, 滿洲醫學雑誌, 24 卷, 昭和

Gerhard Wiele,: Die Prognose der Pneumomie, D. M. W. Nr 45, 1940, 1233 1236. 11 年, $635-676$.

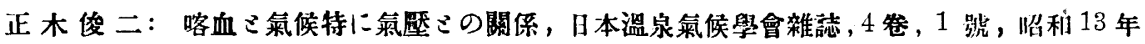
1 14.

星野重雄：咯血さ氣象きの關係，日本溫泉氣侯學會雜誌 4 卷口號，炤和 13 年, 146 153.

田爪, 山口：死とさ氣候ミの關係に就きての統計的觀察, 日本溫泉氣候學會雜誌, 3 卷, 1 號, 昭和 12 年 36〜52.

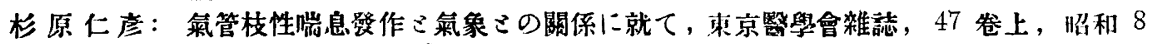
年, 542 569.

H. Berg: Eklampsie und Wetter, Biok. Biok. Beib 6, 148 155, 1939. (抄)

Konrad. Büitner: Physikahiche Bisklimatologie akad, Verlagsgesellschaft, Leipzig, 1938 (抄).

岡崎稳, 石崎達：氣候療法に關寸万研究 (第 2 间報告), 日本溫泉氣候學會雜誌, 6 卷, 1 胧 昭和 15 年, $57 \sim 63$. 